\title{
Persepsi Penderita Diabetes Mellitus Terhadap Partisipasi Aktivitas Latihan Fisik
}

\author{
${ }^{1}$ Selly Riski Putri, ${ }^{2}$ Ulfa Kumala, ${ }^{3}$ Muhammad Ibnu Nazar, ${ }^{4}$ Mutiara Sabta \\ Amanda, ${ }^{5}$ Ahmada Norma Syinta, ${ }^{6}$ Farid Rahman \\ Program Studi Fisioterapi, Fakultas Ilmu Kesehatan, Universitas Muhammadiyah Surakarta \\ Jalan Ahmad Yani, Pabelan, Kartasura, Surakarta Jawa Tengah Indonesia 57162 \\ Email : J120190004@student.ums.ac.id
}

Tanggal Submisi : 25 Oktober 2021 ; Tanggal Penerimaan: 3 Desember 2021

\begin{abstract}
ABSTRAK
Latar belakang: Diabetes Mellitus (DM) merupakan kelainan pada metabolisme di mana tubuh tidak dapat mengatur dengan baik kadar gula, terkhusus glukosa dalam darah, baik karena sensitivitas yang buruk terhadap protein insulin, atau karena produksi insulin yang tidak memadai oleh pancreas. Aktivitas fisik sangat penting bagi penderita DM, aktivitas latihan fisik ini terdapat kaitannya dengan bagaimana persepsi yang dimiliki oleh penderita DM. Tujuan: penelitian ini bertujuan untuk mengetahui persepsi penderita diabetes mellitus terhadap partisipasi aktivitas Latihan fisik Metode: Metode penelitian yang dilakukan dengan menggunakan pendekatan kuantitatif dengan Physical Activity Questionnaire for Diabetic Patients (PAQ-DP), pengumpulan data bersifat non-interaktif dengan cara mengirimkan kuesioner dalam bentuk google form dan menganalisis PAQ-DP dengan menggunakan skala Likert Hasil: Hasil akhir setelah pengolahan data secara keseluruhan mengenai persepsi penderita diabetes mellitus terhadap patisipasi aktivitas fisik $66 \%$ responden menyatakan penting Kesimpulan: Persepsi penderita diabetes mellitus terhadap patisipasi aktivitas fisik memiliki persepsi yang positif baik
\end{abstract}

Kata kunci: Diabetes mellitus, aktivitas fisik, persepsi

\begin{abstract}
Background: Diabetes Mellitus (DM) is a metabolic disorder in which the body cannot properly regulate sugar levels, especially glucose in the blood, either due to poor sensitivity to insulin protein, or due to inadequate insulin production by the pancreas. Physical activity is very important for people with DM, this physical exercise activity has something to do with how the perception of people with DM is. Objective: This study aims to determine the perception of people with diabetes mellitus on participation in physical exercise activities Methods: The research method was carried out using a quantitative approach with the Physical Activity Questionnaire for Diabetic Patients (PAQ-DP), non-interactive data collection by sending questionnaires in form a google form and analyze the PAQ-DP using a Likert scale Results: The final result after processing the overall data regarding the perception of people with diabetes mellitus on participation in physical activity $66 \%$ of respondents stated it was important Conclusion: Perception of people with diabetes mellitus on participation in physical activity has a positive perception.
\end{abstract}

Keywords: Diabetes mellitus, physical activity, perception

ISSN 2722-9610

E - ISSN 2722-9629 


\section{Pendahuluan}

Diabetes Mellitus sering disebut dengan DM, merupakan kelainan pada metabolisme di mana tubuh tidak dapat mengatur dengan baik kadar gula, terkhusus glukosa dalam darah, baik karena sensitivitas yang buruk terhadap protein insulin, atau karena produksi insulin yang tidak memadai oleh pankreas. Diabetes adalah penyakit metabolik kronis yang ditandai dengan meningkatnya kadar glukosa darah dan sering disebut gula darah yang dari waktu ke waktu menyebabkan kerusakan yang serius pada organ organ seperti mata, saraf, pembuluh darah, ginjal, dan jantung.

Umumnya diabetes mellitus yang terjadi pada orang dewasa adalah diabetes tipe 2, dimana terjadi ketika tubuh menjadi resisten terhadap insulin atau tidak menghasilkan cukup insulin. Dalam 3 tahun terakhir, prevalensi diabetes tipe 2 telah meningkat secara dratis di negara-negara dengan semua tingkat pendapatan. Diabetes tipe 1, yang dulu dikenal sebagai diabetes remaja atau diabetes yang bergantung pada insulin, adalah kondisi kronis di mana pankreas menghasilkan sedikit atau tidak ada insulin dengan sendirinya. Bagi penderita diabetes, akses ke pengobatan yang terjangkau, termasuk insulin, sangat penting untuk kelangsungan hidup mereka. Ada target yang disepakati secara global untuk menghentikan peningkatan diabetes dan obesitas pada tahun 2025.

Penderita diabetes mellitus di Indonesia setiap tahunnya semakin meningkat, menurut World Health Organization memperkirakan jumlah pasien diabetes mellitus di Indonesia khususnya tipe 2 akan meningkat signifikan hingga 16,7 juta pada tahun 2045. Hal ini bisa terjadi bila masyarakat Indonesia masih kurangnya kesadaran bahaya akan penyakit diabetes mellitus dan masih sering menyepelekannya faktor faktor penyebab timbulnya diabetes mellitus. Terdapat fakta fakta 425 juta pasien diabetes pertahun $2017 \mathrm{di}$ dunia. Angka ini diperkirakan akan meningkat sebesar $45 \%$ atau setara dengan 629 juta pasien per tahun 2045. Komplikasi pada jantung dan ginjal menjadi penyebab utama kematian pasien diabetes di dunia. $75 \%$ pasien diabetes pada tahun 2017 berusia 20-64 tahun. Indonesia menempati urutan ke-6 dari sepuluh negara dengan jumlah pasien diabetes tertinggi, yakni 10,3 juta pasien per tahun 2017 dan diperkirakan akan meningkat menjadi 16,7 juta pasien per tahun 2045.

Aktivitas Fisik merupakan setiap gerakan tubuh yang diakibatkan kerja otot rangka dan meningkatkan pengeluaran tenaga serta energi. Secara umum aktivitas fisik dibagi menjadi 3 kategori berdasarkan intensitas dan besaran kalori yang digunakan yaitu : aktivitas fisik ringan, aktivitas fisik sedang dan aktivitas fisik berat (Kementerian Kesehatan Republik Indonesia). Dalam literatur disebutkan bahwa yang salah satu cara terbaik untuk mencegah dan mengobati DM tipe 2 adalah latihan rutin aktivitas fisik. Selain itu, perilaku sedenter digambarkan sebagai satu kesatuan faktor utama yang terkait dengan perkembangan penyakit. Penelitian sebelumnya telah menunjukkan hal itu pada manusia yang meningkatkan aktivitas fisik mereka sebagai bagian dari intervensi gaya hidup, kejadian DM adalah 39\% lebih rendah dibandingkan dengan yang hanya menerima metformin, efek ini lebih jelas di antara mereka orang-orang yang lansia. Internasional Diabetes Federation (IDF) merekomendasikan untuk melakukan aktivitas fisik setidaknya antara tiga hingga lima hari dalam seminggu, minimal 30-45 menit

Masih banyak penderita diabetes mellitus yang tidak mengetahui bahwa dirinya terkena diabetes mellitus, dikarenakan kurangnya informasi yang di dapatkan penderita, baik faktor penyebab dan jumlah kasus maupun prevalensi 
diabetes terus meningkat selama beberapa tahun terakhir. Walaupun demekian aktivitas latihan fisik terdapat kaitannya dengan Persepsi. Persepsi merupakan salah satu aspek kognitif manusia yang sangat penting, yang memungkinkannya untuk mengetahui dan memahami dunia sekelilingnya.

Menurut Penelitian Zakiyah A et, al. (2019) terhadap pasien DM yang ada di puskesmas Rowosari, Semarang. Hasil penelitian menunjukkan bahwa responden penelitian ini sebagian besar memiliki persepsi manfaat yang baik mengenai aktivitas fisik bagi penderita DM yaitu sebanyak $70 \%$. responden yang tidak patuh dalam melakukan aktivitas fisik paling banyak ada pada responden yang memiliki persepsi manfaat buruk yaitu sebanyak $66,7 \%$.

Berdasarkan penelitian Hays \& Clark (1999) dalam Hasbi (2012) menyatakan bahwa ditemukan adanya hubungan persepsi manfaat penderita DM dengan perilaku olahraga pada usia lanjut pada African American di Mempis Amerika Serikat. Penelitian ini juga menunjukkan bahwa penderita DM di wilayah kerja puskesmas Praya memiliki persepsi hambatan baik yang berarti penderita DM di puskesmas praya tersebut menganggap hambatan untuk melakukan olahraga atau latihan aktivitas fisik adalah kecil, Berdasarkan hubungan persepsi dengan partisipasi penderita diabetes mellitus menarik penulis untuk melakukan penelitian ini.

\section{Metode Penelitian}

Metode penelitian adalah cara-cara ilmiah yang dilakukan untuk mendaptkan data yang valid, dengan tujuan dapat ditemukan, dikembangkan, dan dibuktikan, suau pengetahuan tertentu sehingga pada gilirannya dapat digunakan untuk memahami, memecahkan, mengantisipasi dan memecahkan masalah (Sugiyono, 2009).

Metode penelitian yang dilakukan dengan menggunakan pendekatan kuantitatif dengan Physical Activity Questionnaire for
Diabetic Patients (PAQ-DP). Persepsi penderita diabetes mellitus sebagai variabel (x) atau bebas dan partisipasi aktivitas latihan fisik sebagai variabel (y) atau terikat. Hipotesis pada penelitian kali ini yaitu sikap, norma subjektif, dan kontrol perilaku yang dirasakan sehingga memunculkan niat untuk melakukan aktivitas latihan fisik. Sikap mengacu pada pribadi faktor suka atau tidak suka, norma subjektif mengacu pada persepsi individu tentang tekanan sosial, dan persepsi kontrol perilaku mengacu pada kepercayaan yang dirasakan seseorang dalam kemampuan untuk melakukan suatu perilaku. Sampel yang diambil dalam penelitian ini adalah pasien diabetes mellitus.

Pengumpulan data bersifat non-interaktif dengan cara mengirimkan kuesioner dalam bentuk google form. Penelitian ini dilakukan di Kabupaten Blora dan dilaksanakan di bulan Juni sampai Agustus 2021. Sampel penelitian ini diambil dari 25 responden dengan kriteria inklusi responden yaitu pasien diabetes mellitus yang berusia 20 tahun sampai 60 tahun dari berbagai profesi, pasien tersebut merupakan masyarakat Blora, Jawa tengah. Serta kriteria ekslusi yaitu pasien yang bukan penderita diabetes mellitus, pasien diabetes mellitus yang berusia $<20$ tahun dan $>60$ tahun dan yang bukan masyarakat Blora, Jawa tengah.

Untuk menganalisis PAQ-DP tersebut dengan menggunakan skala Likert. Skala Likert adalah skala yang digunakan untuk mengukur persepsi, sikap atau pendapat seseorang atau kelompok mengenai sebuah peristiwa atau fenomena sosial (Bahrun, Alifah, \& Mulyono, 2018; Saputra \& Nugroho, 2017). Kebutuhan akan aktivitas latihan fisik dinilai menggunakan skala peringkat 5 point, yaitu sangat penting, penting, kurang penting, tidak penting, dan sangat tidak penting.

Cara untuk menerjemahkan hasil skala likert adalah dengan analisis interval. Agar dapat dihitung dalam bentuk kuantitatif, jawaban dari 
responden diberi bobot atau skor. Bobot atau skor yang diberikan untuk pernyataan ini misalnya Sangat Setuju Penting $(\mathrm{SP})=5$, Penting $(\mathrm{P})=4$, Kurang Penting $(\mathrm{KP})=3$, Tidak penting $(\mathrm{TP})=2$, dan Sangat Tidak Penting $($ STP $)=1$. Perhitungan dengan skala Likert seperti berikut : Setuju Penting $(\mathrm{SP})=$ jumlah responden $\times 5$, Penting $(\mathrm{P})$ $=$ jumlah responden $\mathrm{x} 4$, Kurang Penting $(\mathrm{KP})=$ jumlah responden $\times 3$, Tidak penting $(\mathrm{TP})=$ jumlah responden $\mathrm{x}$ 2, Sangat Tidak Penting $(\mathrm{STP})=$ jumlah responden $\mathrm{x} 1$, kemudian total semua skor. Skor maksimum = (jumlah responden $\mathrm{x}$ skor tertinggi likert $)$, Skor minimum $=($ jumlah responden $\mathrm{x}$ skor terendah likert), Indeks $(\%)=$ (Total Skor / Skor Maksimum) x 100. Setelah setiap pertanyaan diketahui indeksnya maka jumlahkan indeks dari semua pertanyaan dibagi jumlah pertanyaan untuk menentukan hasil akhirnya.

\section{Hasil}

Pada penelitian kali ini mengenai persepsi pederita diabetes mellitus terhadap partisipasi aktivitas fisik yang dilakukan terhadap penderita diabetes mellitus masyarakat Blora, Jawa Tengah dari usia 20-60 tahun serta dari berbagai profesi, laki-laki dan perempuan, dengan jumlah sample 25 responden diperoleh hasil sebagai berikut:

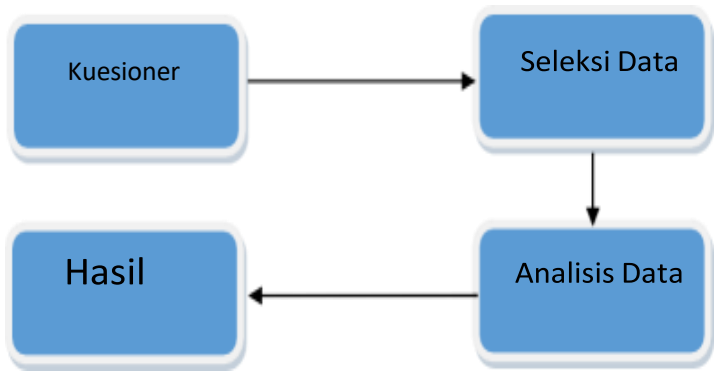

Gambar 1. Gambar 1. Berikut alur penelitian 


\begin{tabular}{|c|c|c|c|c|c|c|c|}
\hline No & $\begin{array}{c}\text { Sangat } \\
\text { Penting } \\
\text { (bobot 5) }\end{array}$ & $\begin{array}{c}\text { Penting } \\
\text { (bobot 4) }\end{array}$ & $\begin{array}{c}\text { Tidak } \\
\text { Keduanya } \\
\text { (bobot 3) }\end{array}$ & $\begin{array}{c}\text { Tidak } \\
\text { Penting } \\
\text { (bobot 2) }\end{array}$ & $\begin{array}{c}\text { Sangat } \\
\text { tidak } \\
\text { Penting } \\
\text { (bobot 1) }\end{array}$ & $\begin{array}{c}\text { Jmlh x } \\
\text { bobot }\end{array}$ & Hasil persentase \\
\hline $\mathrm{P} 1$ & 9 Org & 16 Org & 0 Org & Org & 0 Org & 109 & $87,2 \%$ \\
\hline $\mathrm{P} 2$ & 12 Org & 13 Org & 0 Org & Org & 0 Org & 112 & $89,6 \%$ \\
\hline P3 & 11 Org & 14 Org & 0 Org & Org & OOrg & 111 & $88,8 \%$ \\
\hline $\mathrm{P} 4$ & 2 Org & 21 Org & 2 Org & Org & 0 Org & 100 & $80 \%$ \\
\hline P5 & 4 Org & 21 Org & 0 Org & Org & 0 Org & 104 & $83,2 \%$ \\
\hline P6 & 3 Org & 22 Org & 0 Org & Org & 0 Org & 103 & $82,4 \%$ \\
\hline P7 & 3 Org & 20 Org & 0 Org & 2 Org & 0 Org & 99 & $79,2 \%$ \\
\hline P8 & 0 Org & 3 Org & 0 Org & 22 Org & 0 Org & 56 & $44,8 \%$ \\
\hline P9 & 0 Org & 3 Org & 0 Org & 22 Org & 0 Org & 56 & $44,8 \%$ \\
\hline P10 & 0 Org & 10 Org & 0 Org & 15 Org & 0 Org & 70 & $56 \%$ \\
\hline P11 & 9 Org & 16 Org & 0 Org & 0 Org & 0 Org & 109 & $87,2 \%$ \\
\hline P12 & 7 Org & 18 Org & 0 Org & 0 Org & 0 Org & 107 & $85,6 \%$ \\
\hline P13 & 6 Org & 19 Org & 0 Org & 0 Org & 0 Org & 106 & $84,8 \%$ \\
\hline P14 & 2 Org & 22 Org & 1 Org & 0 Org & 0 Org & 98 & $80,8 \%$ \\
\hline P15 & 1 Org & 23 Org & 1 Org & 0 Org & 0 Org & 100 & $80 \%$ \\
\hline P16 & 1 Org & 24 Org & 0 Org & 0 Org & 0 Org & 101 & $80,8 \%$ \\
\hline Total & 70 Org & 265 Org & 4 Org & 61 Org & 0 Org & 1.544 & $77,2 \%$ \\
\hline
\end{tabular}

Tabel 1. Hasil Analisa skala likert pertanyaan pada kuesioner

Dari Analisa menggunakan skala likert yang tertera pada tabel dapat didapatkan penjabaran hasil sebagai berikut :

Pada pertanyaan 1 tentang melakukan aktivitas fisik sedang selama 30 menit minimal 5 hari seminggu pemahaman masyarakat yang menjadi responden didapatkan hasil bahwa $87,2 \%$ responden menyatakan bahwa sangat bermanfaat. Pada pertanyaan 2 tentang melakukan aktivitas fisik sedang selama 30 menit minimal 5 hari seminggu di dapatkan hasil bahwa $89,6 \%$ responden menyatakan bahwa sangat berharga. Pada pertanyaan 3 tentang melakukan aktivitas fisik sedang selama 30 menit minimal 5 hari seminggu didapatkan hasil $88,8 \%$ responden menyatakan akan sangat baik. Pada pertanyaan ke 4 tentang melakukan aktivitas fisik sedang selama 30 menit minimal 5 hari seminggu didapatkan 
hasil $80 \%$ responden menyatakan akan sangat santai atau rileks. Pada pertanyaan ke 5 mengenai orang yang penting bagi saya berpikir saya harus melakukan aktivitas fisik sedang selama 30 menit setidaknya 5 hari dalam seminggu didapatkan hasil bahwa 83,2\% dari responden sangat setuju. Pada pertanyaan 6 tentang Orang yang penting bagi saya ingin saya melakukan aktivitas fisik sedang 30 menit minimal 5 hari seminggu didapatkan hasil presentase bahwa $82,4 \%$ responden menyatakan sangat setuju. Pada pertanyaan 7 tentang Orang yang penting bagi saya akan mengharapkan saya melakukan aktivitas fisik sedang 30 menit minimal 5 hari seminggu didapatkan hasil presentase $79,2 \%$ responden menyatakan setuju. Pada pertanyaan 8 mengenai saya mendapat tekanan dari keluarga atau teman saya untuk melakukan aktivitas fisik sedang 30 menit minimal 5 hari seminggu didapatkan hasil presentase $44,8 \%$ responden menyatakan tidak keduanya antara setuju dan tidak setuju atau masih ragu-ragu. Pada pertanyaan 9 tentang bagi saya untuk melakukan aktivitas fisik sedang 30 menit minimal 5 hari seminggu itu sulit didapatkan hasil $44,8 \%$ responden menyatakan tidak keduanya antara setuju dan tidak setuju atau masih ragu-ragu. Pada pertanyaan 10 tentang melakukan aktivitas fisik sedang 30 menit minimal 5 hari seminggu terserah saya didapatkan hasil presentasi 56\% responden menyatakan tidak keduanya atau masih ragu. Pada pertanyaan 11 mengenai seberapa besar kemungkinan akan membuat keputusan untuk melakukan aktivitas fisik sedang selama 30 menit setidaknya 5 hari seminggu di bulan berikutnya dan didapatkan hasil presentasi bahwa $87,2 \%$ responden menyatakan sangat mungkin. Pada pertanyaan 12 tentang saya berharap untuk melakukan aktivitas fisik sedang 30 menit setidaknya 5 hari seminggu didapatkan hasil $85,6 \%$ responden menyatakan sangat mungkin. Pada pertanyaan 13 mengenai melakukan aktivitas fisik sedang 30 menit minimal 5 hari seminggu didapatkan hasil $84,8 \%$ responden menyatakan akan sangat menyenangkan. Pada pertanyaan 14 tentang melakukan aktivitas fisik sedang 30 menit minimal 5 hari seminggu akan membuat saya didapatkan hasil persentase $80,8 \%$ responden menyatakan sehat. Pada pertanyaan 15 tentang saya melihat diri saya sebagai orang yang senang berolahraga didapatkan hasil presentasi $80 \%$ menyatakan sangat senang. Pertanyaan terakhir tentang saya melihat diri saya bugar dan sehat didapatkan hasil presentase $77,2 \%$ responden menyatakan bugar dan sehat.

\section{Pembahasan}

Hasil keseluruhan yang didapat melalui pertanyaan pada kuesioner penelitian tersebut didapatkan hasil akhir mengenai persepsi penderita diabetes mellitus terhadap aktivitas fisik yang sesuai dengan diagram dibawah ini:

Gambar 2. Diagram Hasil akhir penelitian persepsi penderita diabetes mellitus terhadap patisipasi aktivitas fisik

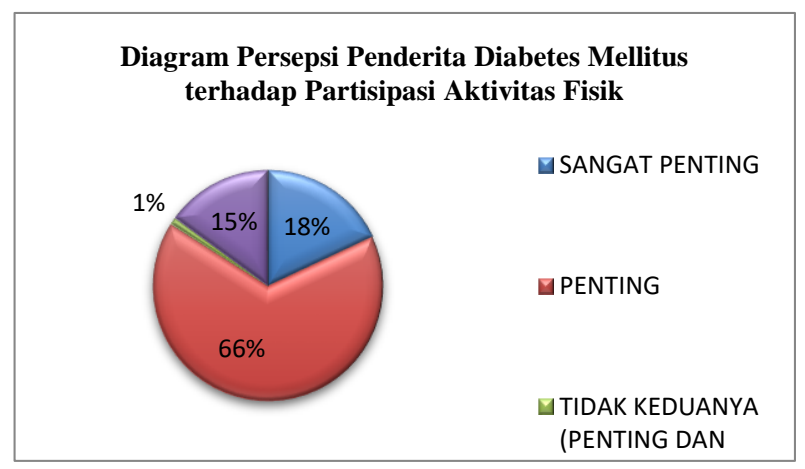

Berdasarkan gambar diagram tersebut dapat dilihat hasil akhir setelah pengolahan data secara keseluruhan mengenai persepsi penderita diabetes mellitus terhadap patisipasi aktivitas fisik didapatkan hasil bahwa sebesar $1 \%$ responden menyatakan tidak keduanya atau ragu, 15\% responden menyatakan tidak penting, $18 \%$ responden menyatakan sangat penting dan $66 \%$ responden menyatakan penting. Dari hasil tersebut dapat disimpulkan bahwa persepsi 
penderita diabetes mellitus terhadap patisipasi aktivitas fisik memiliki persepsi yang positif baik bahwa patisipasi dalam melakukan aktivitas fisik merupakan hal yang penting bagi kesehatan mereka.

Hasil penelitian ini dibuktikan juga sejalan dengan penelitian oleh penelitian Zakiyyah et al., (2019) yang dilakukan pada penderita DM yang berkunjung ke Puskesmas Rowosari, Semarang dengan jumlah sample sebanyak 1293 responden menunjukkan hasil bahwa sebagian besar responden memiliki persepsi manfaat yang baik (70\%). Hasil ini didukung pula oleh penelitian dari Hays \& Clark (1999) dalam Hasbi (2012) yang dilakukan terhadap penderita DM di puskesmas Praya menunjukkan hasil bahwa responden memiliki persepsi hambatan baik yang berarti responden tersebut menganggap hambatan untuk melakukan olahraga atau latihan aktivitas fisik adalah kecil.

\section{Kesimpulan dan Saran}

Dari hasil penelitian yang telah dilakukan melalui media google form, yang telah di sebarkan pada tanggal 12 Juni 2021 kepada masyarakat Kabupaten Blora, Jawa Tengah didapatkan hasil bahwa sebesar $1 \%$ responden menyatakan tidak keduanya atau ragu, 15\% responden menyatakan tidak penting, $18 \%$ responden menyatakan sangat penting dan $66 \%$ responden menyatakan penting. Dari hasil tersebut dapat disimpulkan bahwa persepsi penderita diabetes mellitus terhadap patisipasi aktivitas fisik memiliki persepsi yang positif baik bahwa patisipasi dalam melakukan aktivitas fisik merupakan hal yang penting bagi kesehatan mereka sendiri.

Berdasarkan survey secara daring dengan menggunakan media google form mengenai penelitian yang berjudul "Persepsi Penderita Diabetes Mellitus Terhadap Partisipasi Aktivitas Latihan Fisik" pada masyarakat Blora, Jawa Tengah. Penulis memberikan saran sebaiknya kegiatan ini dilaksanakan secara offline agar sesuai sasaran dan juga fokus pada pencapaian yang akan yang akan diteliti,

\section{Ucapan Terimakasih}

Pada penyusunan penelitian yang sederhana ini, penulis mendapat bantuan dari berbagai pihak. Oleh karena itu penulis mengucapkan terima kasih kepada Bapak Farid Rahman, S.St., Ft., M.Or., Ftr., AIFO sebagai Pembimbing Dosen serta ucapan terimakasih kepada tim penyusun yang berperan aktif selama proses penyusunan. Ucapan terima kasih juga kami disampaikan kepada semua pihak yang tidak dapat disebutkan satu persatu

\section{Daftar Pustaka}

Al-Ghamdi, S., Ahmad, G., Hassan Ali, A., Bahakim, N., Alomran, S., Alhowikan, W., Almutairi, S., Basalem, T., \& Aljuaid, F. (2018). Al Kharj diabetic patients' perception about diabetes mellitus using revised-illness perception questionnaire (IPQ-R). BMC Family Practice, 19(1), 1824. https://doi.org/10.1186/s12875-0180713-x

Azurin, Chester Ryan. Diabetes. Physiopedia. Diakses pada 21 Mei 2021. https://www.physiopedia.com/Diabetes?utm _source=physiopedia\&utm_medi um=search\&utm_campaign=ongoing_int ernal

Bahrun, S., Alifah, S., \& Mulyono, S. (2018). Rancang Bangun Sistem Informasi Survey Pemasaran Dan Penjualan Berbasis Web. TRANSISTOR Elektro Dan Informatika, 2(2), 81-88. http://dx.doi.org/10.30659/ei.2.2.\%25p

Ferriolli, E., Pessanha, F. P. A. S., \& Marchesi, J. C. L. S. (2014). Diabetes and exercise in the elderly. Medicine and Sport Science, $\quad 60, \quad 122-129$. https://doi.org/10.1159/000357342 
Ghazanfari, Zeinab \& Niknami, Shamsaddin \& Ghofranipour, Fazloolah \& Hajizadeh, Ebrahim \& Montazeri, Ali. (2010). Development and psychometric properties of a belief based Physical Activity Questionnaire for Diabetic Patients (PAQDP). BMC medical research methodology. 10. 104. 10.1186/14712288-10-104.

Muhlisa, M., \& BSA, A. (2018). Kepatuhan Medikasi Penderita Diabetes Mellitus Berdasarkan Teori Health Belief Model (HBM) Di Diabetes Center Kota Ternate Tahun 2017. Interest: Jurnal Ilmu Kesehatan, $\quad 7(2), \quad$ 144-149. https://doi.org/10.37341/interest.v7i2.23

Puspitasari, Leny. (2020). Angka Diabetes di Indonesia Semakin Tinggi, Berikut Faktanya!. Siloam Hospital. Diakses pada 21 Mei 2021

https://www.siloamhospitals.com/Conten

ts/News-

Events/Advertorial/2020/01/31/02/10/Angk a-Diabetes-di-Indonesia-Semakin- Tinggi-

Berikut-

Faktanya\#: :text=Indonesia\%20menempati

\%20urutan\%20ke\%2D6,juta\%20

pasien\%20per\%20tahun\%202045

Zakiyyah, A., Nugraha, P., \& Indraswari, R. (2019). Faktor-Faktor Yang Berhubungan Dengan Kepatuhan Aktivitas Fisik Penderita Dm Untuk Pencegahan Komplikasi Di Wilayah Kerja. Ejournal3.Undip.Ac.Id, $7, \quad 453-462$. https://ejournal3.undip.ac.id/index.php/jkm/ article/view/23067 